\title{
Bio-signature of Ultraviolet-Radiation-Resistant Extremophiles from Elevated Land
}

\author{
Prashant Gabani ${ }^{1}$, Dhan Prakash², Om V. Singh ${ }^{1, *}$ \\ ${ }^{1}$ Division of Biological and Health Sciences, University of Pittsburgh, Bradford, PA, USA \\ ${ }^{2}$ Department of Environmental Hydrology and Microbiology, Ben-Gurion University of the Negev, Sede-Boquer Campus, Israel \\ *Corresponding author: ovs11@pitt.edu, ovs11@yahoo.com
}

Received May 06, 2014; Revised May 27, 2014; Accepted May 29, 2014

\begin{abstract}
Microorganisms with the ability to survive high doses of radiation are known as radiation-resistant extremophiles. This study attempts to demonstrate the diversity of microorganisms resistant to ultraviolet radiation (UVR) in the natural environment in order to investigate the molecular and physiological mechanisms by which these microorganisms survive under extreme radiation. We hypothesized that topsoil from elevated land (hills) would reveal a diverse variety of UVR-resistant extremophiles with modulated proteins/enzymes. A total of 10 different UV-C (UV subtype-C)-resistant extremophiles-UVP1, UVP3, UVP4, UVR1, UVR3, UVR4, UVR5a, UV20hr, YLP1, and BR2-were isolated and identified using 16S rRNA sequences for nearest homologues. All the isolates showed prolonged resistance against UV-C: $3.44 \times 10^{5}-2.74 \times 10^{6} \mathrm{~J} / \mathrm{m}^{2}$. Phylogenetic analysis between and within the UVR isolates revealed their relationship with other soil microorganisms using different outgroups. A unique pattern of protein expression at 25-50kDa was observed on SDS-PAGE under UVR and non-UVR from six prominent UVR isolates. Current studies are finding extreme UV-C-resistant in naturally occurring microorganisms found in stress-free environments.
\end{abstract}

Keywords: extremophiles, microorganisms, ultraviolet radiation (UVR), elevated land, phylogenetic diversity, proteins

Cite This Article: Prashant Gabani, Dhan Prakash, and Om V. Singh, "Bio-signature of UltravioletRadiation-Resistant Extremophiles from Elevated Land.” American Journal of Microbiological Research, vol. 2, no. 3 (2014): 94-104. doi: 10.12691/ajmr-2-3-3.

\section{Introduction}

Some habitats have environmental conditions, e.g. acidic, alkaline, high and low temperatures including intense ultraviolet radiation (UVR) requiring extreme endurance from the microorganisms that colonize them. Microorganisms thriving under these environments are referred as extremophiles [1,2,3]. Radiation prone environment (e.g. ultraviolet type $\mathrm{C}$ or gamma radiation) could be a good source for microorganisms with altered phenotypic and genotypic characteristics [2,3]. A number of physiological and biochemical processes have been reported to be affected by UVR [2,3,4]. In bacteria, UVRmediated stress may increase resistance to the error-prone repair mechanism that led to cellular survival in the presence of unrepaired lesions during DNA replication $[5,6]$.

UVR causes a variety of harmful health effects including premature aging and skin cancer in humans [2,7]. Genomic redundancy is supposed to be good for radiation resistance [8]. In addition, the oxidative damages due to UVR led to damage of vital biomolecules, including proteins, in most cellular types. However, some bacteria adapt to survive under extreme irradiation, which is otherwise lethal to the environment. In the past UVR- resistant bacteria that have been isolated include Bacillus horneckiae, isolated from spacecraft assembly [9], Hymenobacter tibetensis [10], Stenotrophomonas maltophila, Exiguobacterium sp., and Staphylococcus sp. [11]. Recent studies has shown occurrence of UV-C tolerant bacteria on ground [48]. However, the diversity of UVR- resistant bacterial on ground is yet to be explored.

Microbial ability to survive in extreme UVR is reviewed to connect with their genome stability $[2,41,47,49]$. Several other UVR-resistant bacteria have been revealed to produce metabolites of primary and secondary metabolism in their defense [2,12]. However, these metabolites have yet to be investigated for their mechanistic intervention. The modern biotechnological applications may assist to pinpoint the microbial strategy of self-engineering to withstand under extreme UVR. Hence, it is required to demonstrate the diversity of UVRresistant microorganisms from the natural environment on earth to investigate the physiological mechanisms by which they survive under extreme UVR. We hypothesized that the elevated land (hills) would reveal a diverse variety of UVR-resistant extremophiles with modulated proteins/enzymes. Therefore, we aimed to isolate and characterize the diversity of microorganisms resistant to UVR subtype C (UV-C) in soil at the Tracy Ridge recreational area located in Northern Pennsylvania, USA, $2245 \mathrm{ft}$ above the sea level. The 16S rRNA and detailed 
biochemical characteristics of the 10 isolates demonstrated unique diversity of UVR extremophiles among other soil microorganisms. Further, studies showed prolonged survival among six UV-C isolates with unique protein expression profiles.

\section{Experimental Section}

\subsection{Isolation of UVR-resistant Extremophiles}

The UVR-resistant microorganisms were isolated as described by Gabani et al. [13]. Briefly, the soil samples collected at the Tracy Ridge recreation area, 2245 feet above the sea level, in the Allegheny National Forest of northwestern Pennsylvania, USA in the month of August. The soil samples (1g) were enriched aerobically in a widemouthed glass bowls $(105 \times 40 \mathrm{~mm})$ in $50 \mathrm{~mL}$ nutrient broth (NB) medium, at $37^{\circ} \mathrm{C}$. The bowls were exposed to germicidal UV light subtype C (UVC) at an intensity of $9.5 \mathrm{~W} / \mathrm{m}^{2}$. The enriched soil samples were subjected to serial dilutions, and determined for Colony Forming Unit (CFU)/mL on nutrient agar (NA) medium. After exposure to UVC, the rate of survival was determined at regular time intervals at $9.5 \mathrm{~J} / \mathrm{m}^{2} / \mathrm{sec}$ using CFU. The UVRresistant microorganisms were obtained at UV exposure $3.44 \times 10^{5} \mathrm{~J} / \mathrm{m}^{2}$ to $4.10 \times 10^{6} \mathrm{~J} / \mathrm{m}^{2}$ and were designated as UVP1, UVP3, UVP4, UVR1, UVR3, UVR4, UVR5a, UV20hr, YLP1, and BR2. After UV exposure, the growth of individual isolates were determined at $\mathrm{OD}_{600}$. $16 \mathrm{~S}$ rRNA sequencing and biochemical analysis was performed to identify and characterize the UVR isolates for their phylogenetic relationship among other closest relatives.

\subsection{Sequence Alignments and Phylogenetic Tree Analyses}

The genomics DNA from single cell purified colonies was extracted using PureLink ${ }^{\mathrm{TM}}$ Genomic DNA MiniKit K1820-01 (Invitrogen Corp., USA) as per manufacturer's instructions. The 16S rRNA gene sequences from UVR resistance isolates were amplified using universal primer (F-518: CCAGCAGCCGCGGTAATACG, R-800: TACCAGGGTATCTAATCC) and sequenced at Macrogen Service Center (Rockville, MD, USA). The obtained sequences were computed for closest relatives from EzTaxon Server Version 2.1 (www.eztaxon.org) and Ribosomal Database Project (RDP) release 10 (http://rdp.cme.msu.edu/index.jsp). The phylogenetic trees were constructed by the neighbor-joining method (NJ) with pairwise deletion of gaps in the RDP database. The NJ method was used to construct the phylogenetic trees and study the diversity among UVR resistance extremophiles with naturally occurring microorganisms.

\subsection{Nucleotide Sequence Accession Numbers}

The 16S rRNA sequences of all pure cultures were deposited in the GenBank database under accession numbers JQ348903, JQ348901, JQ348902, KC866375, KC866376, KC866377, KC866378, KC866379, KC866380, KC866381 for Cellulosimicrobium cellulans UVP1, Enterobacter sp.UVP3, Bacillus pumilus UVP4, Raoultella planticola UVR1, Bacillus stratosphericus UVR3, Aeromonas eucrenophila UVR4, Arthrobacter mysorens UVR5a,
Micrococcus yunnanensis UV20hr, Stenotrophomonas YLP1, and Brevundimonas olei BR2 respectively.

\subsection{Morphological and Physiological Characterization}

Isolates were examined for colony morphology on NA medium at $37^{0} \mathrm{C}$ for $3-5$ days. The cellular morphology was investigated using light microscopy (Zeiss) at x1000 magnification. The microbial motility among isolates was determined as described by Skerman [14]. Gram reaction was determined using the Gram Stain Kit (Carolina Biological Supply, Burlington, NC, USA) as per manufacturer's instructions. The biochemical test i.e. Physiological tests [15], catalase activity and urea hydrolysis [16], hydrolysis of casein, gelatin, elastin, Tween 80 and starch [17] were performed in respective methods. The Voges- Proskauer, methyl red, oxidation/fermentation (OF), growth on citrate agar and MacConkey agar, production of $\mathrm{H}_{2} \mathrm{~S}$ and indole was performed as described by Goodfellow [16]. The oxidase activity [17], acid production using bromocresol purple as an acid/base indicator was also determined [18]. The antibiotics sensitivity was tested using antibioticsusceptibility discs supplied by (Carolina Biological Supply, Burlington, NC, USA). Isolates UVP1, UVP3, UVP4, UVR1, UVR3, UVR4, UVR5a, UV20HR, YLP1, and BR2 were subjected to other biochemical tests using the Bergey's Manual of Systematic Bacteriology [19], shown in the supplementary material (S1).

\subsection{UV Radiation Tolerance}

The UVR resistance among isolates was characterized as described by Gabani et al. [13]. Briefly, the seed cultures $(1 \%)$ of each isolate $\left(\mathrm{OD}_{600} 1.25\right)$ were inoculated in a glass bowl (105 x $40 \mathrm{~mm})$ containing $50 \mathrm{~mL}$ NB medium. The medium was exposed to germicidal UV-C lamp at radiation dosages of $3.44 \times 10^{5} \mathrm{~J} / \mathrm{m}^{2}$ to $4.10 \times 10^{6}$ $\mathrm{J} / \mathrm{m}^{2}$ at $37^{\circ} \mathrm{C}$. Under sterile condition, the culture medium then transferred in to $250 \mathrm{~mL}$ Erlenmeyer flask and incubated in dark at $120 \mathrm{rpm}$ at $37^{\circ} \mathrm{C}$. The microbial growth was monitored at regular time intervals at $\mathrm{OD}_{600}$. Three sets of experiments were accompanied with controls performed under similar conditions for UV- and non-UV exposure, selecting UV-sensitive E. coli as the control.

\subsection{SDS-PAGE of UV-modulated Protein Expression}

The protein modulation among UVR resistant extremophiles was characterized as described by Gabani et al. [13]. Briefly, total soluble protein was extracted and purified using a B-PER bacterial protein extraction reagent kit from Pierce (IL, USA) as per manufacturer's instructions from UV and non-UV exposed microorganisms. The soluble protein in cellular lysate was determined for total protein concentration using a RC DC protein assay kit (BIO-Rad, CA, USA) as per manufacturer's instructions. Protein samples were aliquoted and stored at $-80^{\circ} \mathrm{C}$ until used. Required sample of total protein $(75 \mu \mathrm{g})$ was denatured in sample buffer (60 $\mathrm{mM}$ Tris (pH 6.8), 25\% glycerol, 2\%SDS, $14.4 \mathrm{mM} 2-$ mercaptoethanol, and $0.1 \%$ bromophenol blue). The samples were cooled on ice and centrifuges prior loading 
on to $10 \%$ Tris-glycine gel along with pre-strained molecular weight marker. Gel electrophoresis was performed using the Bio-Rad Mini Protein gel system at a constant voltage of $60 \mathrm{~V}$ for $30 \mathrm{~min}$ followed by $120 \mathrm{~V}$ for 120 min or until the blue dye front reached the bottom of the gel. The resolved proteins were visualized by standard gel staining procedure using Coomassie Brilliant Blue dye (BIO-Rad, CA, USA) and imaged by regular HP scanner for further analysis.

\section{Results and Discussion}

\subsection{Occurrence of Microorganisms at Higher Altitudes and UVR}

Following long-term exposure of the soil samples to 9.5 $\mathrm{J} / \mathrm{m}^{2} / \mathrm{sec}$ UV-C radiation, the overall number of bacterial colony-forming units (CFUs) in samples exposed to UVR was significantly lower than in the samples not exposed to UV-C radiation over the whole study period $(P<0.01)$ (Figure 1). The initial dose of UV-C (3.44 x $\left.104 \mathrm{~J} / \mathrm{m}^{2}\right)$ was found to be the most lethal $\left(3.27 \times 10^{5}\right.$ CFUs under UV-C vs. $6.60 \times 10^{14}$ CFUs under no radiation). CFU counts of UVR-resistant organisms consistently increased up to 6.89 $\mathrm{x} 10^{5} \mathrm{~J} / \mathrm{m}^{2}$ and stayed nearly constant up to $1.54 \times 10^{6} \mathrm{~J} / \mathrm{m}^{2}$ UV-C exposures; however, the CFUs significantly decreased at $2.06 \times 10^{6} \mathrm{~J} / \mathrm{m}^{2}$ of UV-C and beyond (Figure 1). The average survivability of the UVR-resistant organisms was found to be $0.12 \%$ over the course of UV exposure at $4.10 \times 10^{6} \mathrm{~J} / \mathrm{m}^{2}$. The average survivability peaked at $7.43 \%$ with $6.89 \times 10^{5} \mathrm{~J} / \mathrm{m}^{2} \mathrm{UV}-\mathrm{C}$ dose.

The soil from the elevated land (Tracy Ridge recreation area) contained a wide diversity of UV-C-resistant microorganisms. Based on their physical appearances (i.e., color and colony morphology), a total of 10 different microorganisms were isolated from the nutrient-brothenriched soil samples under UV-C and designated as UVP1, UVP3, UVP4, UVR1, UVR3, UVR4, UVR5a, UV20hr, YLP1, and BR2 over a wide range of UV-C dosage (Table 1). The microbial flora in identified microbial community from elevated land contained microorganisms resistant to a wide range of $\mathrm{UV}-\mathrm{C}$ radiation ranging from $3.44 \times 10^{5} \mathrm{~J} / \mathrm{m}^{2}$ to $4.10 \times 10^{6} \mathrm{~J} / \mathrm{m}^{2}$. The strain UVR1 was found to be the most resistant to $\mathrm{UV}-\mathrm{C}$ radiation at $4.10 \times 10^{6} \mathrm{~J} / \mathrm{m}^{2}$ dosage.

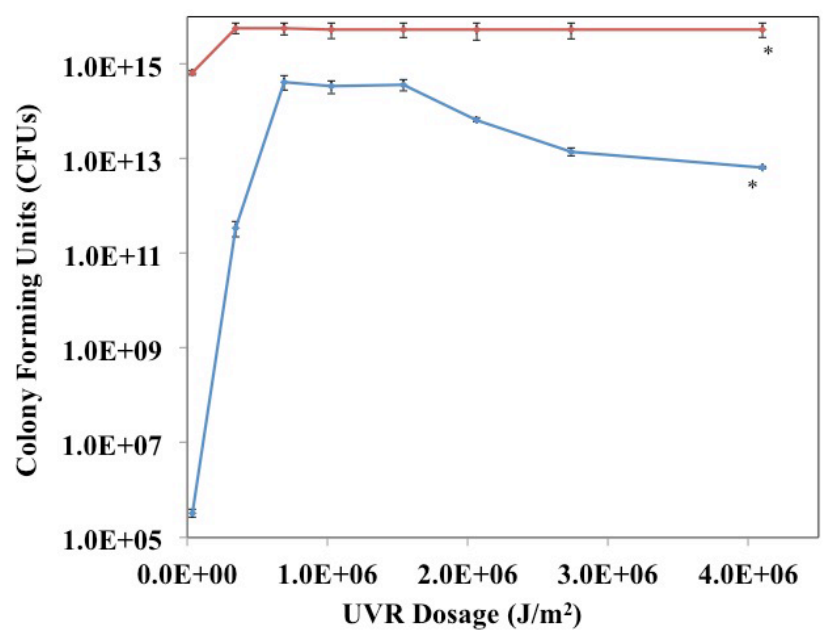

Figure 1. Survivability of total bacteria from elevated land soil at varying UV-C exposure. The soil samples were enriched in nutrient broth in a wide mouth glass bowl under germicidal UV lamp (subtype C) at $9.5 \mathrm{~W} / \mathrm{m}^{2}$ at $32^{\circ} \mathrm{C}$. Colony Forming Units were observed at regular intervals using serial dilution method. The colony forming units under UVR and non-UVR represented by blue $\left({ }^{*} P<0.01\right)$ and red lines $\left({ }^{*} P<0.01\right)$, respectively

Table 1. 16S rRNA sequence homologues of Ultraviolet radiation (UV subtype -C) resistant isolates from elevated land

\begin{tabular}{llcll}
\hline Isolates & UVR resistance & GenBank Accession Number & Closest related Species & 16S rRNA similarity Score* \\
\hline UVP1 & $1.03 \times 10^{6} \mathrm{~J} / \mathrm{m}^{2}$ & JQ348903 & Cellulosimicrobium cellulans \\
UVP3 & $1.03 \times 10^{6} \mathrm{~J} / \mathrm{m}^{2}$ & JQ348901 & Enterobacter sp. \\
UVP4 & $3.44 \times 10^{5} \mathrm{~J} / \mathrm{m}^{2}$ & JQ348902 & Bacillus pumilus & 0.998 \\
UVR1 & $4.10 \times 10^{6} \mathrm{~J} / \mathrm{m}^{2}$ & KC866375 & Raoultella planticola \\
UVR3 & $2.74 \times 10^{6} \mathrm{~J} / \mathrm{m}^{2}$ & KC866376 & Bacillus stratosphericus \\
UVR4 & $1.54 \times 10^{6} \mathrm{~J} / \mathrm{m}^{2}$ & KC866377 & Aeromonas eucrenophila \\
UVR5a & $6.84 \times 10^{5} \mathrm{~J} / \mathrm{m}^{2}$ & KC866378 & Arthrobacter mysorens \\
UV20HR & $6.84 \times 10^{5} \mathrm{~J} / \mathrm{m}^{2}$ & KC866379 & Micrococcus yunnanensis \\
YLP1 & $2.05 \times 10^{6} \mathrm{~J} / \mathrm{m}^{2}$ & KC866380 & Stenotrophomonas sp. \\
BR2 & $1.54 \times 10^{6} \mathrm{~J} / \mathrm{m}^{2}$ & KC866381 & Brevundimonas olei \\
\hline
\end{tabular}

*Based on Ribosomal Database Project (RDP) release 10 (http://rdp.cme.msu.edu/index.jsp)

Microbial life is known to be transported across the globe via atmospheric strata, therefore it is common to observe a variety of microbial life in different atmospheric layers, mostly radiation-prone environment [20,21]. Microorganisms (i.e. Bacteria and fungi) have been found at altitudes of up to $85 \mathrm{~km}$ [22], stratospheric air samples collected at $41 \mathrm{~km}$ [23] and $24 \mathrm{~km}$ above the earth [24]. A number of microbial species have been isolated from the NASA Jet Propulsion Laboratories Spacecraft Assembly Facility (JPL-SAF) [25], and Mars Odyssey spacecraft [26]. Microorganism Cellulosimicrobium cellulans was isolated from Antarctic snow and showed marked variability in its cellular composition and metabolic capabilities compared to its mesophilic counterpart [27].

In order to develop new therapies, it is vital to study organisms that can thrive under extreme UVR on Earth. UVR-resistant microorganisms have shown tremendous stable biotechnological implications [2,3,29,30]. The short exposure of UV is generally known for random mutagenesis, however microbial reversion may produce unstable mutants with commercially viability. The prolonged exposure to UVR in certain microorganisms may bring stable changes to their genomes, creating resistance by modifying their metabolic routes to thrive in a high-UVR environment. 

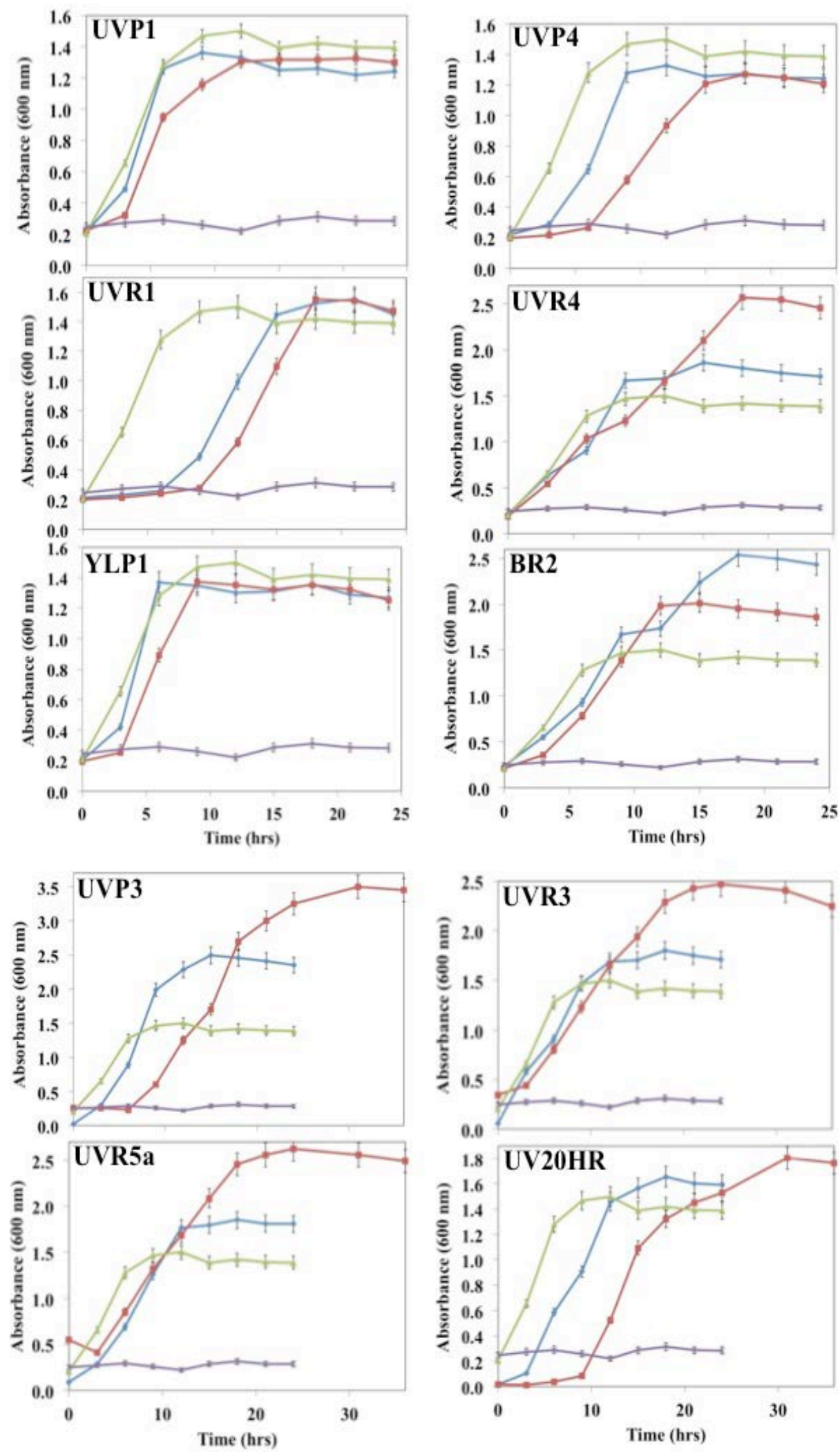

Figure 2. Growth of selective UVR resistant isolates. The isolates UVP1, UVP4, UVR1, UVR4, YLP1, BR2, UVP3, UVR3, UVR5a, and UV20HR were grown in nutrient broth after exposing under UV-C radiation dosage of $1.03 \times 10^{6} \mathrm{~J} / \mathrm{m}^{2}, 3.44 \times 10^{5} \mathrm{~J} / \mathrm{m}^{2}, 4.10 \times 10^{6} \mathrm{~J} / \mathrm{m}^{2}, 1.54 \times 10^{6} \mathrm{~J} / \mathrm{m}^{2}, 2.05 \times 10^{6} \mathrm{~J} / \mathrm{m}^{2}$, $1.54 \times 10^{6} \mathrm{~J} / \mathrm{m}^{2}, 1.03 \times 10^{6} \mathrm{~J} / \mathrm{m}^{2}, 2.74 \times 10^{6} \mathrm{~J} / \mathrm{m}^{2}, 6.84 \times 10^{5} \mathrm{~J} / \mathrm{m}^{2}$, and $6.84 \times 10^{5} \mathrm{~J} / \mathrm{m}^{2}$. The growth of isolates under UV-C (red), non-UV (blue) including UV sensitive $E$. coli as a control under UV-C (purple) and non-UV (green) was determined at regular interval at $\mathrm{OD}_{600}$

The limits of UV tolerance were investigated in natural soil microbial flora (bacteria) found in the Tracy Ridge recreational area in Pennsylvania, USA (Figure 1, Figure 2). The Tracy Ridge recreational area is only $2245 \mathrm{ft}$ above sea level and thus not a good environment for high dosages of UV-C radiation. The isolates presented here may have accumulated mutations through natural causes (solar radiation, seasonal changes, etc.) that allow them to withstand higher levels of UV-C despite the absence of the selective pressure of high UVR in their natural habitat. Microorganisms resistant to UVR have previously been found in samples from very high elevations such as the Laguna Azul [31], aquatic environments, halophilic environments [8], and spacecraft assembly [26,32]. 
However, for the first time, current studies are finding UV-C-resistant microorganisms in stress-free environments.

\subsection{Tolerance and Survivability of UVR- Resistant Extremophiles}

Radiation tolerance among the isolates was determined by exposing each isolate to the UV-C radiation dosage at which they were isolated: UVP1 at $1.03 \times 10^{6} \mathrm{~J} / \mathrm{m}^{2}$, UVP4 at $3.44 \times 10^{5} \mathrm{~J} / \mathrm{m}^{2}$, etc. (Table 1 ). The growth was measured $\left(\mathrm{OD}_{600}\right)$ at regular intervals for 24 hours (Figure 2). The UV tolerance of each isolate was compared to that of unexposed isolates and the growth of UV-sensitive $E$. coli. A typical Lag, Exponential, Stationary, and Decline (LESD) curve of microbial growth was observed for all the isolates, both exposed and unexposed to UV-C radiation (Figure 2). Varied lag phases (2-10 hrs) were observed among the isolates. The culture of UV-sensitive $E$. coli did not grow under UV irradiation, but showed a normal LESD curve under non-UV conditions.

It is likely that tolerance of UVR in different microbial types depends on their strategies for adapting to the slow progression of radiation prone environment. Of the types of solar radiation UV-C $(180-280 \mathrm{~nm})$ is eliminated by the stratospheric ozone layer and UV-B (280-320 or $315 \mathrm{~nm}$ ) reaches partway to the surface, while there is complete exposure to UV-A (315-400 nm). However, the steady increase in greenhouse gases and ozone depletion in the stratosphere is enforcing further microbial adaptation in natural and engineered microbial communities [33,34,35].

UV-C resistance was observed in the common natural soil bacteria Cellulosimicrobium cellulans (UVP1), Raoultella ornithinolytica (UVR1), Aeromonas eucrenophila (UVR4), Micrococcus yannanensis (UV20HR), and Enterobacter sp. (UVP3) (Figure 2), which have not been previously reported. However, the microorganism Stenotrophomonas maltophilia has previously been isolated from Andean lakes and found to be resistant to UV-B radiation [11]. UV-C-radiationresistant Arthrobacter sp. and Bacillus pumilus have been isolated from the Atacama Desert, able to withstand 1000 $\mathrm{J} / \mathrm{m}^{2} \mathrm{UV}-\mathrm{C}$ radiation [30]. Microorganism Brevundimonas sp. is known to be a resistant to UV-C, gamma radiations and hydrogen peroxide [36,37]. B. pumilus has been well known for its UVR resistance [28,32,38].

Our studies indicated prolonged resistance in $B$. pumilus UVP4 to a $3.44 \times 10^{5} \mathrm{~J} / \mathrm{m}^{2}$ dosage of UV-C radiation (Table 1; Figure 2). The strain of $B$. pumilus exhibited here showed the highest degree of UV resistance compared to other known Bacillus sp. [32]. Gioia et al. [29] have reported several genes involved in DNA repair and oxidative stress (dinG, disA, dnaE, mutL, ogt, pcrB, polA, polY2, recD, sms, uvrX, uvrA, uvrB, sodA, sodF, $b c r C$, and many more caused by UV-C radiation). Two novel species of Bacillus, $B$. nealsonii, isolated from a spacecraft assembly facility, and $B$. odysseyi, were resistant to UV radiation [39,40]. Shivaji et al. [24] reported four novel strains: $B$. aerius $24 \mathrm{~K}^{\mathrm{T}}, B$. aerophilus $28 \mathrm{~K}^{\mathrm{T}}$, B. stratosphericus $41 \mathrm{KF}^{2} \mathrm{a}^{\mathrm{T}}$, and $B$. altitudinis $41 \mathrm{KF} 2 \mathrm{~b}^{\mathrm{T}}$. The UV-C-resistant strains UVP4 (B. pumilus) and UVR3 (B. stratosphericus) showed a resemblance to their nearest phylogenetic neighbors (Figure 3, C and E). All ten isolates showed phylogenetic relationships between themselves; however, they also showed differences from one another (Figure 4A-C).

UVR-resistant microorganisms have the potential to thrive in environments with high radiation levels, such as nuclear waste fields [41]. Pigmentation has been known to protect organisms against UVR. The presence of yellow pigments in isolates UVR4 (Aeromonas eucrenophila), UVR5a (Arthrobacter mysorens), UV20HR (Micrococcus yunnanensis), YLP1 (Stenotrophomonas sp.), and brown in isolate BR2 (Brevundimonas olei) could be responsible for their resistance to UV-C radiation. The biochemical data clearly reveal uniqueness among isolates (Supplementary material- S1). Some other microorganisms have been reported to produce pigments that are highly resistant to UVR [22,31]. The cyanobacterium Tolypothrix byssoidea from the exposed rock surface of an Indian temple [42], and Chroococcidiopsis from the desert [35] were reported to have UV-protecting pigments. The molecular mechanism by which natural microorganisms adapt themselves has yet to be discovered, but a hypothetical mechanism by which radiation-responsive extremolytes can allow the survival of radiation extremophiles has been suggested [2]

\subsection{Identification and Phylogenetic Relationship of UVR-resistant Organisms}

The isolates obtained under UV-C irradiation were characterized and identified according to their closest homologue from the 16S rRNA gene that was amplified and sequenced from genomic DNA. The 16S rRNA sequencing revealed 947 bp, 957 bp, 954 bp, 526 bp, 954 bp, 530 bp, 961 bp, 959 bp, 948 bp, and 471 bp sequences of UVP1, UVP3, UVP4, UVR1, UVR3, UVR4, UVR5a, UV20HR, YLP1, and BR2 respectively. The sequences were compared with those of other closely related taxa retrieved from GenBank in the ribosomal database and the EzTaxon online search engine. The 16S rRNA sequences' homology and topology of the phylogenetic tree indicated that the radiation-resistant isolates-UVP1, UVP4, UVR1, UVR3, UVR4, UVR5a, UV20HR, YLP1, and BR2-were phylogenetically related to the members of the family Promicromonosporaceae, Enterobacteriaceae, Bacillaceae, Aeromonadaceae, Micrococcaceae (UVR5a and UV20HR), Xanthomonadaceae, and Caulobacteraceae, respectively (Figure 3A-J). Isolates UVP3 and YLP1 had the nearest relationship with Enterobacter sp. and Stenotrophomonas sp., respectively (Figure 3B and I). The phylogenetic analysis revealed prominent phylogenetic relationships among isolates using three common extremophiles as outgroups (Salimicrobium luteum, Saccharococcus thermophiles, and Bacillus subtilis) (Figure 4A-C). 16S rRNA sequences of each isolates were deposited in the GenBank database under accession numbers JQ348903, JQ348901, JQ348902, KC866375, KC866376, KC866377, KC866378, KC866379, KC866380, and KC866381 for Cellulosimicrobium cellulans UVP1, Enterobacter sp. UVP3, Bacillus pumilus UVP4, Raoultella planticola UVR1, Bacillus stratosphericus UVR3, Aeromonas eucrenophila UVR4, Arthrobacter mysorens UVR5a, Micrococcus yunnanensis UV20hr, Stenotrophomonas YLP1, and Brevundimonas olei BR2 respectively. 

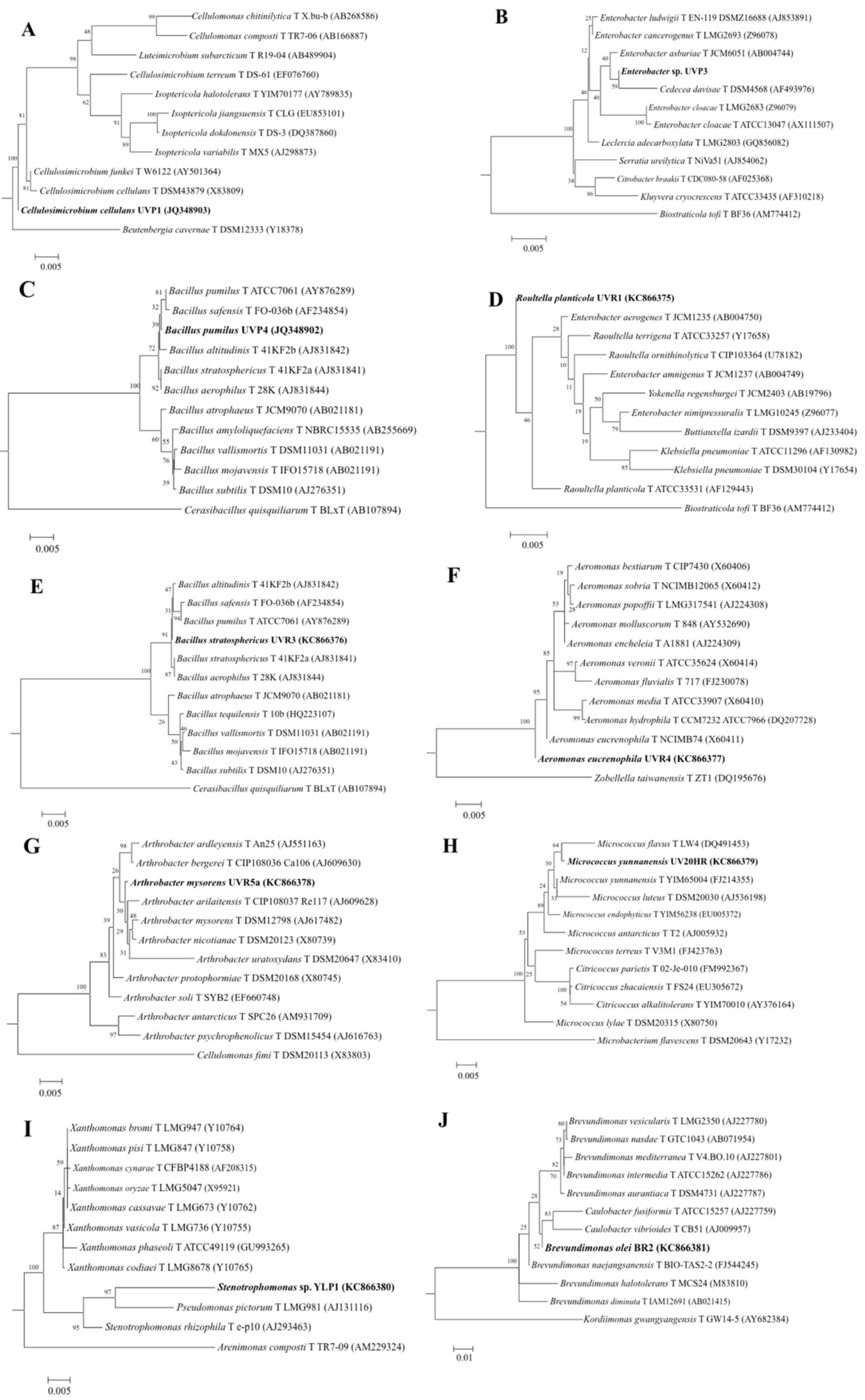

Figure 3. 16S rRNA gene sequence based neighbor-joining phylogenetic tree showing relationship between UVR radiation resistant isolates (A-J) showing close proximity with respective homologues. As revealed in A-J, different out groups were used for each UVR isolates. Numbers at the nodes indicate levels of bootstrap support based on neighbor-joining analysis of 1000 resampled datasets. GenBank accession numbers are given in parenthesis. Bar, 5 substitution for 1000 nucleotide positions. (Figure 3A and Figure 3C adopted and modified from Singh et al., 2012 with permission) 
Based on the 16S rRNA sequence homologues, the isolates were subjected to biochemical characterization for further identification that matched to $16 \mathrm{~S}$ rRNA sequence homologues. The identities of all the isolates were
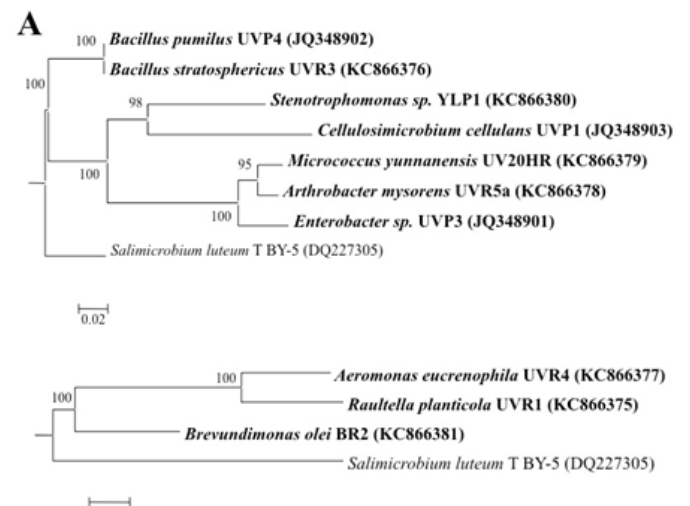

C

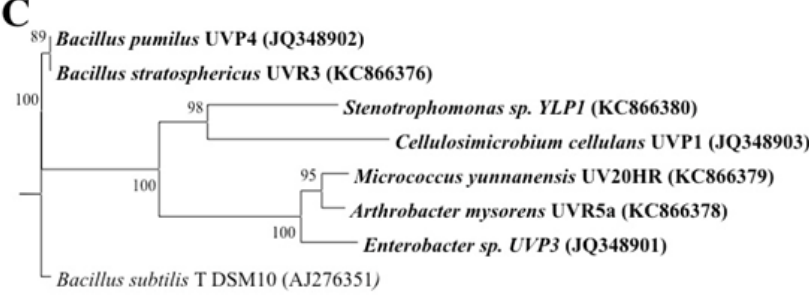

$\stackrel{\leftrightarrow}{\circ}$
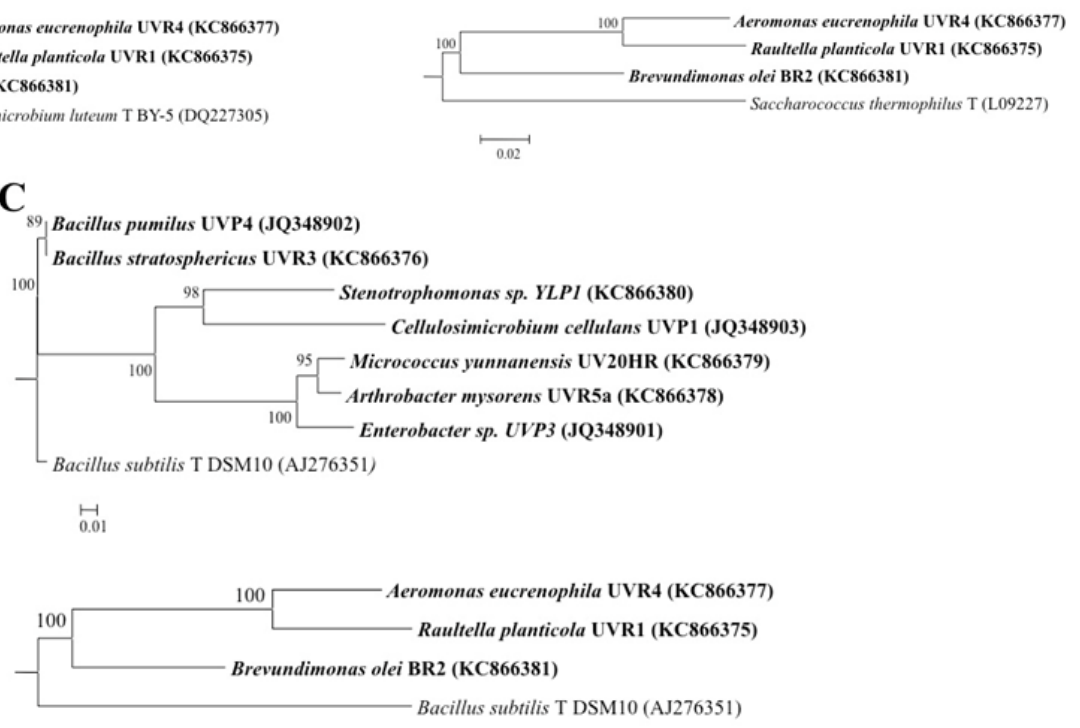
biochemical tests using Bergey's manual of Systematic Bacteriology (Vol 1,1984) as shown in supplementary material (S1).

B

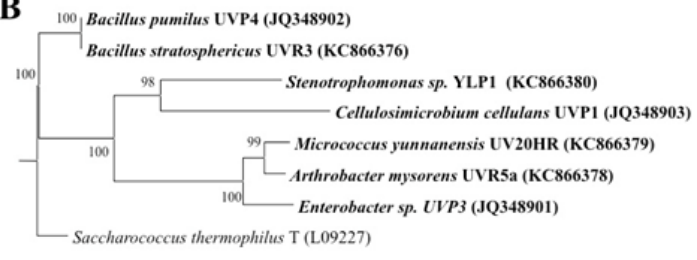

$\longmapsto$

$\stackrel{\longmapsto}{\longmapsto_{02}}$

Figure 4. 16SrRNA gene sequence based neighbor-joining phylogenetic tree showing relationship within UVR radiation resistant isolates (A-C) reveal phylogenetic relationship among themselves with respective out groups. Numbers at the nodes indicate levels of bootstrap support based on neighborjoining analysis of 1000 resampled datasets. GenBank accession numbers are given in parenthesis. Bar, 5 substitution for 1000 nucleotide positions

\subsection{D Proteome of UVR-resistant Microorganisms}

The cellular-survivability-responsive unique radiationsensitive proteins/enzymes were resolved on onedimensional (1D) SDS-PAGE. The total protein profiles of UVR-resistant isolates (UVP1, UVR4, UVR1, UVP4, $\mathrm{BR} 2$, and YLP1) revealed unique protein bands expressed at similar molecular weight ranges, 25-100 $\mathrm{kDa}$, compared with those in the absence of UVR (Figure 5). The radiation-sensitive species-specific protein expression is clearly visible in dominance among isolates grown under UVR conditions at $37^{\circ} \mathrm{C}$ (Figure 5A) compared to isolates that were not exposed to UVR (Figure 5B). Isolates UVP1, UVR4, and UVP4 revealed unique protein expression under UV versus non-UVR (Figure 5A and B) at different molecular weights ranging from 25 to $50 \mathrm{kDa}$. Protein identification using liquid chromatography-mass spectrometry (LC-MS/MS) is subject to further research into protein- and enzyme-based survivability among UVR-resistant isolates.

The total protein profile using SDS-PAGE (Figure 5A and B) vary in protein expression based on the respective molecular weight in the presence and absence of UVR for respective UV-C intensity (Table 1). Among the UVRresistant isolates (UVP1, UVR4, UVR1, UVP4, BR2, and
YLP1), unique protein bands were expressed at similar molecular weight ranges, 25-100 kDa, compared with non-UV-C-exposed bacteria in Coomassie blue-stained gel images (Figure 5A and $\mathrm{B}$ ).

The genomic integrity of bacteria have been reported to be affected by UVR in Chroococcidiopsis and Deinococcus radiodurans [35,43]. The genomic instability should reveal alterations in the downstream targets, i.e., proteins and enzymes. In a proteomics analysis of gammaradiation-resistant Bacillus sp. HKG 112, two proteins$38 \mathrm{kDaflagellin}$ and $86.5 \mathrm{kDa}$ S-layer protein-showed significant changes after radiation exposure [44]. Liedert et al. [45] reported that in D. geothermalis, there were 34 abundant proteins that had no known function; these might relate to the extreme stress tolerance of the organism. Another comparative proteomic analysis of $D$. radioduranse and $D$. deserti revealed that the histone-like DNA-binding protein HU was the most abundant protein among the nucleoid-associated proteins [46]. In the current study, isolates UVP1, UVR4, and UVP4 showed unique protein expression under UV versus non-UVR (Figure 5A and $\mathrm{B}$ ) at different molecular weights ranging from 25 to $50 \mathrm{kDa}$. Protein identification using liquid chromatography-mass spectrometry (LC-MS/MS) is subject to further research into protein- and enzyme-based survivability among UVR-resistant isolates. 


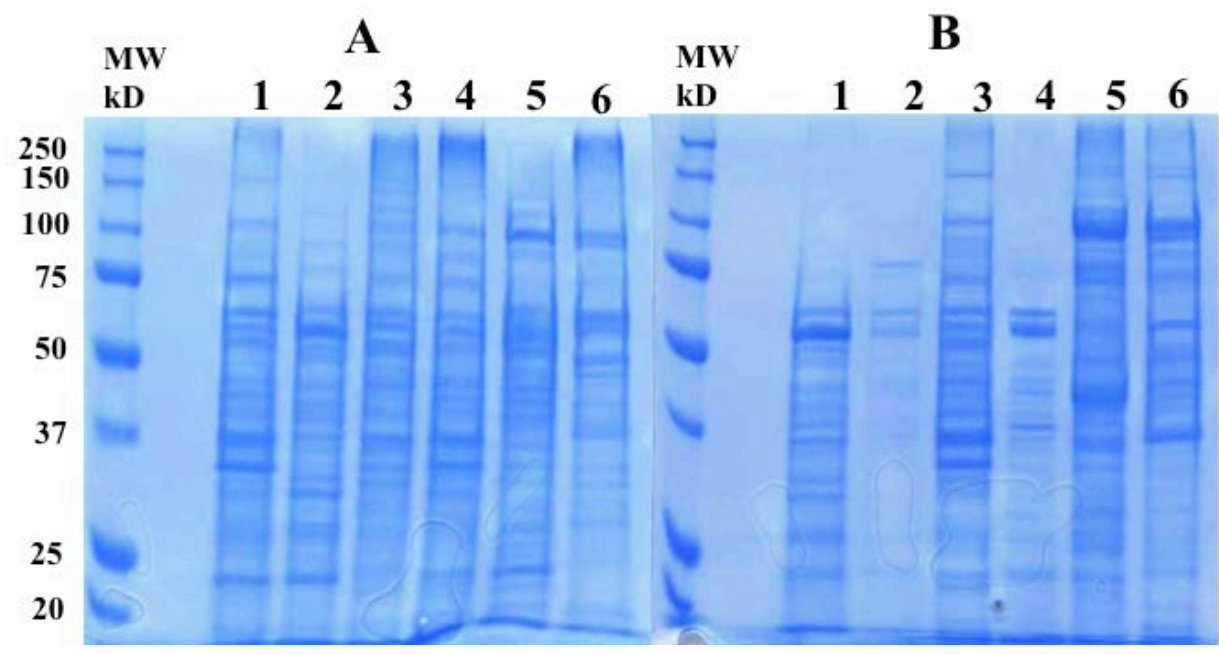

Figure 5. Differential protein expression profile of UVR resistant isolates. (Total $(75 \mu \mathrm{g})$ cytosolic protein from UVR isolated was extracted and resolved on 10\% SDS-PAGE as detailed in methods. The differences in protein expression profile revealed induction of proteins after UV irradiation in UVR isolated (A) compared to non-UV (B) (Lane information: MW- molecular weight marker (kD); 1- UVP-1; 2- UVR-4; 3- UVR-1; 4- UVP-4; 5- Br2; 6-YLP-1)

\section{Conclusions}

Despite the harmful effects of radiation on humans, current studies reveal different microorganisms have found ways to survive under high levels of radiation The ability of the organisms isolated in our study to withstand high dosages of UV-C radiation could help us to explore the potential benefits on Earth including bioremediation of radioactive wastes [47] and bioenergy [13] and life in extraterrestrial environments. A total of 10 different UVC-resistant isolates were identified. Based on our methods of isolating the microorganisms, it is proposed that direct UV irradiation of natural samples can be used to isolate additional UV-resistant organisms from the environment. The ability of isolates to survive in UVR needs to be further investigated to identify the roles of the metabolites and pigments in biotechnology and therapeutics.

\section{Acknowledgments}

The authors are thankful for the institutional assistance that made this research possible.

\section{Conflicts of Interest}

The authors declare no conflict of interest.

\section{References}

[1] Mesbah NM, Wiegel J(2012) Life Under Multiple Extreme Conditions: Diversity and Physiology of the Halophilic Alkalithermophiles. Applied Environmental Microbiology 78: 4074-4082.

[2] Singh OV, Gabani P (2011) Extremophiles: radiation resistance microbial reserves and therapeutic implications. Journal of Applied Microbiology 110: 851-861.

[3] Gabani P, Singh OV (2013) Radiation-resistant extremophiles and their potential in biotechnology and therapeutics. Applied Microbiology Biotechnology 97: 993-1004.

[4] Castenholz RW, Garcia-Pichel F. Cyanobacterial responses to UV radiation. In: The ecology of cyanobacteria II: their diversity in space and time, Whitton BA, Eds. Springer, The Netherlands, 2012; pp. 481-499.

[5] Walker GC (1984) Mutagenesis and inducible responses to deoxyribonucleic acid damage in Escherichia coli. Microbiology Review 48: 60-93.

[6] Smith BT, Walker GC (1998) Mutagenesis and more: umuDC and the Escherichia coli SOS response. Genetics 148: 1599-1610.

[7] Agar NS, Halliday GM, Barnetson RS, Ananthaswamy HN, Wheeler M, Jones AM (2004) The basal layer in human squamous tumors harbors more UVA than UVB fingerprint mutations: a role for UVA in human skin carcinogenesis. Proc Nat Acad Sci,USA 101: 4954-4959.

[8] Martin EL, Reinhardt RL, Baum LL, Becker MR, Shaffer JJ, Kokjohn TA (2000) The effects of ultraviolet radiation on the moderate halophile Halomonas elongata and the extreme halophile Halobacterium salinarum. Canadian Journal of Microbiology 46: 180-187.

[9] Vaishampayan P, Probst A, Krishnamurthi S, Ghosh S, Osman S, McDowall A. et al. (2010) Bacillus horneckiae sp. nov., isolated from a spacecraft-assembly clean room. International Journal of Systematic Evolutionary Microbiology 60: 1031-1037.

[10] Dai J, Wang Y, Zhang L, Tang Y, Luo X, An H, Fang C (2009)Hymenobacter tibetensis sp. nov., a UV-resistant bacterium isolated from Qinghai-Tibet plateau. Systematic Applied Microbiology 32: 543-548.

[11] Flores MR, Ordonez OF, Maldonado MJ, Farias ME (2009) Isolation of UV-B resistant bacteria from two high altitude Andean lakes $(4,400 \mathrm{~m})$ with saline and non saline conditions. Journal of General Applied Microbiology 55: 447-458.

[12] Carreto JI, Carignan MO (2011) Mycosporine-like amino acids: relevant secondary metabolites. Chemical and ecological aspects. Marine Drugs 9: 387-446.

[13] Gabani P, Copeland E, Chandel AK, Singh OV (2012) Ultravioletradiation-resistant isolates revealed cellulose-degrading species of Cellulosimicrobiumcellulans (UVP1) and Bacillus pumilus (UVP4). Biotechnology Applied Biochemistry 59: 395-404.

[14] Skerman VBD (1967) A Guide to the Identification of the Genera of Bacteria, 2nd ed. Williams \& Wilkins, Baltimore.

[15] Goodfellow M. Genus Rhodococcus Zopf 1891, 28 ${ }^{\mathrm{AL}}$. In: Bergey's Manual of Systematic Bacteriology, vol 2, Sneath PHA, Mair NS, Sharpe ME, Holt JG Eds., Williams \& Wilkins, Baltimore, 1986, pp. 1472-1481.

[16] Cowan ST, Steel KJ (1965) Manual for the Identification of Medical Bacteria. London: Cambridge University Press.

[17] Smibert RM, Krieg NR. Phenotypic characterization. In: Methods for General and Molecular Bacteriology. Gerhardt P, Murray RGE, Wood WA, Krieg NR Eds. American Society for Microbiology, Washington, DC, 1994, pp. 607-654.

[18] Gordon RE, Barnett DA, Handerhan JE, Pang CH-N (1974) Nocardiacoeliaca, Nocardiaautotrophica, and the nocardin strain. International Journal of Systematic Bacteriology 24:54-63.

[19] Bergeys Manual of Systematic Bacteriology (vol. 1, 1984). 
[20] Bruch CW. Microbes in the upper atmosphere and beyond. In: Airborne Microbes (Society for General Microbiology Symposium no. 17); Gregory PH, Monteith JL Eds.; Cambridge University Press, Cambridge, 1967; pp. 345-373.

[21] Hoyle B, Wickramasinghe NC (1999) Astronomical Origins Of Life: Steps Towards Panspermia. Dordrecht: Kluwer.

[22] Imshenetsky AA, Lysenko SV, Lach SP (1979) Microorganisms of the upper layers of the atmosphere and the protective role of their cell pigments. Life Science Space Research 17: 105-110.

[23] Harris MJ, Wickramasinghe NC, Lloyd D, Narlikar JV, Rajaratnam P, Turner MP. et al. The detection of living cells in stratospheric samples. In: Instruments, Methods and Missions for Astrobiology IV, Proceedings of the SPIE Conference; Hoover RB, Levin GV, Paepe RR, Rozanov AY Eds.; Bellingham, WA: 2001, Volume 4495, pp. 192-198.

[24] Shivaji S, Chaturvedi P, Suresh K, Reddy GS, Dutt CB, Wainwright M, Narlikar JV, Bhargava PM (2006)Bacillus aerius sp. nov., Bacillus aerophilus sp. nov., Bacillus stratosphericus sp. nov. and Bacillus altitudinis sp. nov., isolated from cryogenic tubes used for collecting air samples from high altitudes. International Journal of Systematic Evolutionary Microbiology, 56: 1465-1473.

[25] Venkateswaran K, Satomi M, Chung S, Kern R, Koukol R, Basic C, White D (2001) Molecular microbial diversity of a spacecraft assembly facility. Systematic Applied Microbiology 24: 311-320.

[26] La Duc MT, Nicholson W, Kern R, Venkateswaran K (2003) Microbial characterization of the Mars Odyssey spacecraft and its encapsulation facility. Environmental Microbiology 5: 977-985.

[27] Antony R, Krishnan KP, Thomas S, Abraham WP, Thamban M (2009) Phenotypic and molecular identification of Cellulosimicrobium cellulans isolated from Antarctic snow. Antonie van Leeuwenhoek 96: 627-634.

[28] Benardini JN, Sawyer J, Venkateswaran K, Nicholson WL (2003) Spore UV and acceleration resistance of endolithic Bacillus pumilus and Bacillus subtilis isolates obtained from Sonoran desert basalt: implications for lithopanspermia. Astrobiology 3: 709-717.

[29] Gioia J,Yerrapragada S,Qin X,Jiang H,Igboeli OC,Muzny D (2007). Paradoxical DNA repair and peroxide resistance gene conservation in Bacillus pumilus SAFR-032. PloS One, 2:e928.

[30] Osman S, Peeters Z, La Duc MT, Mancinelli R, Ehrenfreund P, Venkateswaran K (2008) Effect of shadowing on survival of bacteria under conditions simulating the Martian atmosphere and UV radiation. Appllied Environmental Microbiology 74: 959-970.

[31] Zenoff VF, Heredia J, Ferrero M, Sineriz F, Farias ME (2006) Diverse UV-B resistance of culturable bacterial community from high-altitude wetland water. Current Microbiology 52: 359-362.

[32] Link L, Sawyer J, Venkateswaran K, Nicholson W (2004) Extreme spore UV resistance of Bacillus pumilus isolates obtained from an ultraclean Spacecraft Assembly Facility. Microbial Ecology 47: 159-163.

[33] McKenzie RL, Aucamp PJ, Bais AF, Björn LO, Ilyas M, Madronich S (2011) Ozone depletion and climate change: impacts on UV radiation. Photochemistry Photobiology Science 10: 182189.

[34] Schreiber F, Wunderlin P, Udert KM, Wells GF (2012) Nitric oxide and nitrous oxide turnover in natural and engineered microbial communities: biological pathways, chemical reactions, and novel technologies. Frontier Microbiology 3: 372.
[35] Baqué M, Viaggiu E, Scalzi G, Billi D (2013) Endurance of the endolithic desert cyanobacterium Chroococcidiopsis under UVC radiation. Extremophiles 17:161-169.

[36] Ghosh S, Osman S, Vaishampayan P, Venkateswaran K (2010) Recurrent isolation of extremotolerant bacteria from the clean room where Phoenix spacecraft components were assembled. Astrobiology10: 325-335.

[37] Dartnell LR, Hunter SJ, Lovell KV, Coates AJ, Ward JM (2010) Low-temperature ionizing radiation resistance of Deinococcus radiodurans and Antarctic Dry Valley bacteria. Astrobiology 10: 717-732.

[38] Abshire RL, Bain B, Williams T (1980) Resistance and recovery studies on ultraviolet-irradiated spores of Bacillus pumilus. Appllied Environmental Microbiology 39: 695-701.

[39] La Duc MT, Satomi M, Venkateswaran K (2004)Bacillus odysseyi sp. nov., a round spore-forming bacillus isolated from the Mars Odyssey spacecraft. International Journal of Systematic Evolutionary Microbiology 54: 195-201.

[40] Venkateswaran K, Kempf M, Chen F, Satomi M, Nicholson W, Kern R (2003)Bacillus nealsonii sp. nov., isolated from a spacecraft-assembly facility, whose spores are gamma-radiation resistant. International Journal of Systematic Evolutionary Microbiology 53: 165-172.

[41] Bagwell CE, Bhat S, Hawkins GM, Smith BW, Biswas T, Hoover TR. et al. (2008) Survival in nuclear waste, extreme resistance, and potential applications gleaned from the genome sequence of Kineococcus radiotolerans SRS30216. PloS one, 3:e3878.

[42] Adhikary SP, Sahu JK (1998) UV protecting pigments of the terrestrial cyanobacterium Tolypothrixbyssoidea. Journal of Plant Physiology 153: 770-773.

[43] Battista, JR (1997) Against all odds: the survival strategies of Deinococcusradiodurans. Annual Review Microbiology 51: 203224.

[44] Gupta AK, Pathak R, Singh B, Gautam H, Kumar R, Arora R (2011) Proteomic analysis of global changes in protein expression during exposure of gamma radiation in Bacillus sp. HKG 112 isolated from saline soil. Journal of Microbiology Biotechnology 21: 574-581.

[45] Liedert C, Bernhardt J, Albrecht D, Voigt B, Hecker M, SalkinojaSalonen M, Neubauer P (2010) Two-dimensional proteome reference map for the radiation-resistant bacterium Deinococcusgeothermalis. Proteomics 10: 555-563.

[46] de Groot A, Chapon V, Servant P, Christen R, Saux MF, Sommer S, Heulin T (2005) Deinococcusdeserti sp. nov., a gammaradiation tolerant bacterium isolated from the Sahara Desert. International Journal of Systematic Evolutionary Microbiology 55: 2441-2446.

[47] Makarova KS, Aravind L,Wolf YI, Tatusov RL,Minton KW, Koonin EV, Daly MJ (2001) Genome of the extremely radiationresistant bacterium Deinococcusradiodurans viewed from the perspective of comparative genomics. Microbiology Molecular Biology Review 65: 44-79.

[48] Paulino-Lima IG, Azua-Bustos A, Vicuna R, Gonzalez-Silva C, Salas L, Teixeira L, Rosado A, Leitao AA, Lage C (2013) Isolation of UVC-tolerant bacteria from the hyperarid Atacama Desert, Chile. Microbial Ecology 65: 325-335.

[49] Goosen N, Moolenaar GF (2008) Repair of UV damage in bacteria. DNA Repair 7: 353-379.

\section{Supplementary Material}

S1: Morphological, physiological and biochemical tests of UVR resistant microorganisms

\begin{tabular}{|c|c|c|c|c|c|c|c|c|c|c|}
\hline Tests & UVP1 & UVP3 & UVP4 & UVR1 & UVR3 & UVR4 & UVR5a & UV20hr & YLP1 & BR2 \\
\hline \multicolumn{11}{|l|}{$\begin{array}{l}\text { Morphological } \\
\text { tests: }\end{array}$} \\
\hline \multicolumn{11}{|l|}{$\begin{array}{l}\text { Colony } \\
\text { morphology }\end{array}$} \\
\hline Configuration & Round & Round & Round & Round & Round & Round & Round & Round & Round & Round \\
\hline Margin & Entire & Entire & Entire & Entire & Entire & Entire & Entire & Entire & Entire & Entire \\
\hline Elevation & Convex & Convex & Convex & Convex & Convex & Convex & Convex & Convex & Convex & Convex \\
\hline Surface & Smooth & Smooth & Rough & Smooth & Rough & Smooth & Smooth & Rough & Smooth & Smooth \\
\hline Pigment & Cream & Cream & Reddish tinch & Cream & Cream & Yellowish & Yellowish & Yellowish & Yellowish & Brown \\
\hline
\end{tabular}




\begin{tabular}{|c|c|c|c|c|c|c|c|c|c|c|}
\hline Opacity & Opaque & Opaque & Opaque & Opaque & Opaque & Opaque & Opaque & Opaque & Opaque & Opaque \\
\hline $\begin{array}{l}\text { Gram's } \\
\text { reaction }\end{array}$ & -ve & -ve & +ve & -ve & +ve & -ve & + & +ve & -ve & -ve \\
\hline Cell shape & Rods & Rods & Rods & Rods & Rods & Rods & $\begin{array}{l}\text { Rods } \\
\text { \&Coccus }\end{array}$ & Cocci & Rods & Rods \\
\hline Arrangement & Singly & singly & Singly & Single & Singly & $\begin{array}{l}\text { Singly } \\
\text { curve }\end{array}$ & $\begin{array}{l}\text { Rods } \\
\text { \&Coccus } \\
\text { cycle }\end{array}$ & $\begin{array}{l}\text { Singly and } \\
\text { Tetrads }\end{array}$ & Single & Single \\
\hline Spore(s) & - & - & + & - & + & - & - & - & - & - \\
\hline Shape & & & Oval & - & Oval & & - & - & & - \\
\hline Position & & & Central & & Central & & - & - & & \\
\hline Motility & - & + & + & - & + & + & \pm & \pm & + & + \\
\hline Fluorescence & - & - & - & - & - & - & - & - & - & - \\
\hline \multicolumn{11}{|l|}{$\begin{array}{l}\text { Physiological } \\
\text { tests: }\end{array}$} \\
\hline \multicolumn{11}{|l|}{$\begin{array}{l}\text { Growth at } \\
\text { temperatures }\end{array}$} \\
\hline $4^{\circ} \mathrm{C}$ & - & - & - & - & - & - & - & - & - & + \\
\hline $10^{\circ} \mathrm{C}$ & - & - & - & - & - & - & - & - & - & + \\
\hline $15^{\circ} \mathrm{C}$ & - & - & \pm & - & - & + & - & - & - & + \\
\hline $30^{\circ} \mathrm{C}$ & + & + & + & + & + & + & + & + & + & + \\
\hline $37^{\circ} \mathrm{C}$ & + & + & + & + & + & + & + & + & + & \pm \\
\hline $42^{\circ} \mathrm{C}$ & + & \pm & + & - & + & - & - & - & - & - \\
\hline $55^{\circ} \mathrm{C}$ & - & - & \pm & - & \pm & - & - & - & - & - \\
\hline $65^{\circ} \mathrm{C}$ & - & - & - & - & - & - & - & - & - & - \\
\hline \multicolumn{11}{|l|}{ Growth at pH } \\
\hline pH 5.0 & - & - & - & - & - & - & $=$ & - & - & - \\
\hline pH 6.0 & - & + & + & + & + & + & + & + & - & + \\
\hline pH 7.0 & + & + & + & + & + & + & + & + & + & + \\
\hline pH 8.0 & + & + & + & + & + & + & - & + & + & + \\
\hline pH 9.0 & + & + & + & \pm & + & - & - & - & + & + \\
\hline pH 11.0 & - & - & - & - & - & - & - & - & - & - \\
\hline \multicolumn{11}{|l|}{\begin{tabular}{ll|} 
Growth & on \\
$\mathrm{NaCl}(\%)$ & \\
\end{tabular}} \\
\hline 2.5 & + & + & + & + & + & + & + & + & + & \pm \\
\hline 5.0 & + & + & + & - & + & + & \pm & - & + & - \\
\hline 7.0 & - & + & + & - & + & - & - & - & - & - \\
\hline 8.5 & - & - & \pm & - & - & - & - & - & - & - \\
\hline 10 & - & - & - & - & - & - & - & - & - & - \\
\hline \multicolumn{11}{|l|}{$\begin{array}{l}\text { Biochemical } \\
\text { tests: }\end{array}$} \\
\hline $\begin{array}{l}\text { Growth on } \\
\text { MacConkey } \\
\text { agar }\end{array}$ & + & + & - & + & - & - & - & - & + & - \\
\hline Indole test & + & - & - & + & - & + & - & - & + & - \\
\hline Methyl red test & - & - & & - & - & - & - & - & - & - \\
\hline $\begin{array}{l}\text { VogesProskauer } \\
\text { test }\end{array}$ & + & + & + & + & + & + & - & - & - & - \\
\hline $\begin{array}{l}\text { Citrate } \\
\text { utilization } \\
\end{array}$ & + & + & + & + & + & + & + & + & + & + \\
\hline $\mathrm{H}_{2} \mathrm{~S}$ production & - & - & - & - & - & - & - & - & - & - \\
\hline Gas production & + & + & - & - & - & - & - & - & - & - \\
\hline $\begin{array}{l}\text { Casein } \\
\text { hydrolysis }\end{array}$ & + & + & + & + & + & + & + & + & + & - \\
\hline $\begin{array}{l}\text { Gelatin } \\
\text { hydrolysis }\end{array}$ & - & + & + & - & - & + & - & - & + & - \\
\hline $\begin{array}{l}\text { Starch } \\
\text { hydrolysis }\end{array}$ & + & + & - & - & - & + & + & - & + & - \\
\hline Urea hydrolysis & + & + & - & + & - & - & - & - & - & - \\
\hline
\end{tabular}




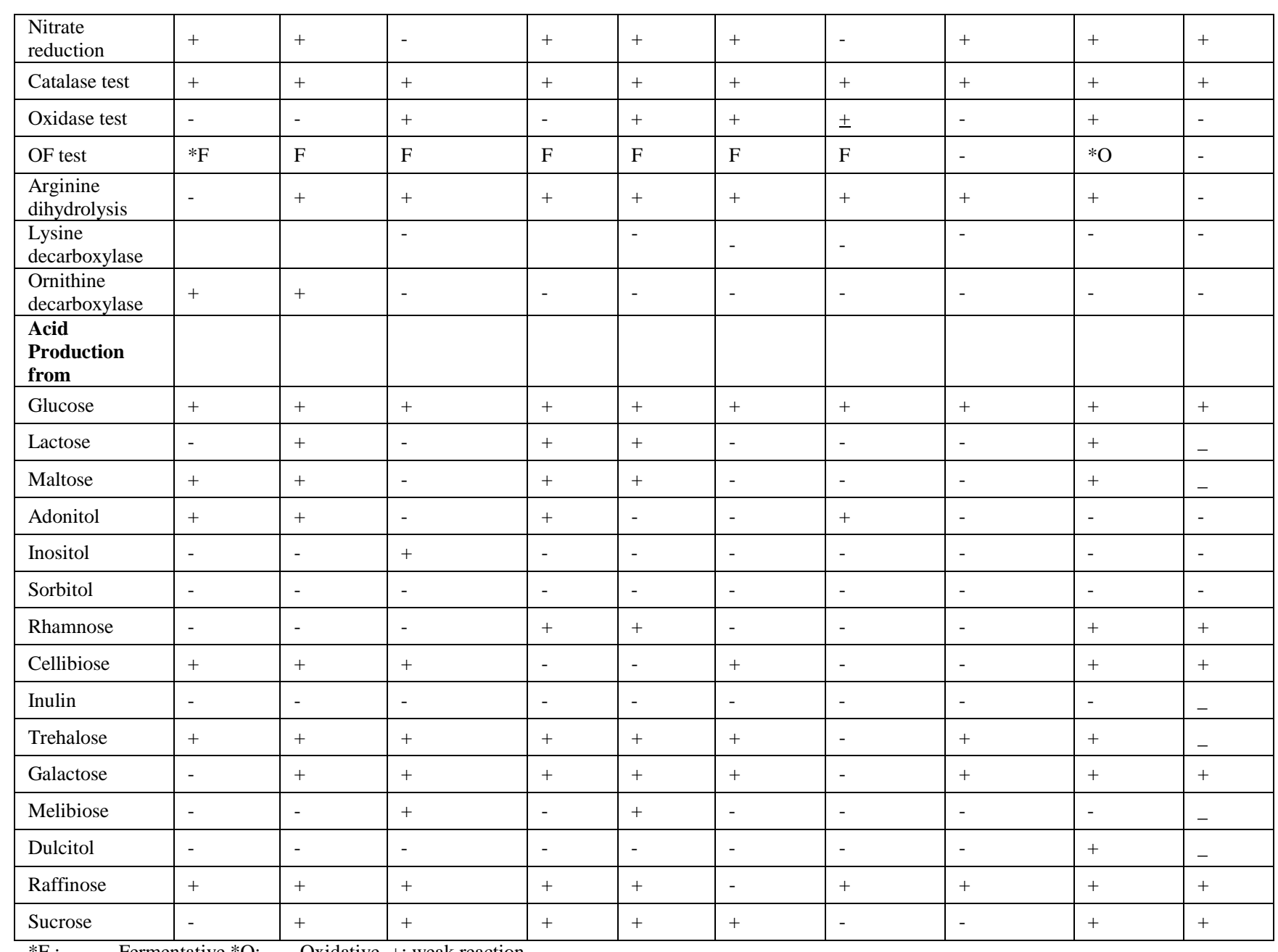

${ }^{*} \mathrm{~F}: \quad$ Fermentative ${ }^{*} \mathrm{O}: \quad$ Oxidative \pm : weak reaction 